\title{
Social and Legal Status of Women in Medieval Georgia
}

\author{
Zurab Targamadze
}

\begin{abstract}
Formation of legislation in medieval Georgia had long term development. It was closely related to both the Eastern and the Western experiences. Law documents are important sources for representation of history of Georgian legislation, however, at the same time, they are providing valuable data on many other aspects of societal life.

In the early middle ages we are faced the distinct status of women in inheritance law. Since 9th century existence of the dowry institute has a great importance to clarify aspects of women's rights. The impression is that women were perceived no longer as an items, but as individuals. Although, it is clear that such attitude was more characteristic for high social stratum.
\end{abstract}

In period of "Golden Age" (XIth-XIIth centuries) of medieval Georgian culture and political ascendance of Georgian state the social position of women became rather strong. Women owned property; they were politically visible and culturally active. The eloquent example of women's promotion in medieval Georgia is of course Queen (always referred as King) Tamar (1184-1213), who is the most venerated and beloved Georgian ruler.

The paper deals with the issue of the social status of women. Their economic relations, property, inheritance and legal rights.

Index Terms-Medieval history, Georgian legislation, law and gender perception.

\section{INTRODUCTION}

In modern world, there is not such a society that is not determined according to sex, where a man has rights and women - duties. Such attitudes originate from the social and cultural past. The problem of acquisition of a human as an accomplished person in any age leads to the perception of gender and the attitude towards the social status of a woman. Science of History is not an exception as well. Most of the concepts were developed without considering the role of a woman while building a society.

The acquisition of masculinity and femininity as a socially constructed phenomena have so enriched and diversified the historical research that the term "past" already sounds absolutely differently. The historical resources that had been put on the shelf because of the informational deficit, have been renewed by the conceptual change in the perception of the past.

Despite the great interest of individual scientist in Georgia, the practice of percepting history from the context of gender is still developing. Anyway, it is the fact that no studying real social roles of society members supported to creation and

\footnotetext{
Manuscript received January 11, 2017; revised March 12, 2017. This work was supported in part by the Rustaveli National Foundation under Doctoral program Grant DO/351/110-14.

Zurab Targamadze is with Ivane Javakhishvili Tbilisi State University, GE, and Exhibition curator of Rustavi History Museum, Georgia (e-mail: zurab.targamadze147@hum.tsu.edu.ge).
}

enforcement of stereotypes.

For us - as interested in research the history of the Georgian ethnic and national identity, the question of women has become an issue since than we have begun to study the impact of the on-going cultural and historical processes on the development of the self-consciousness in the Georgian kingdoms and principalities in the eighteenth century.

Our current goal is to coverage same aspects of women's history in Georgia.

\section{ACTUALITY OF THE ISSUE}

Most of basic words, that are associated with the acquisition of the universe by a Georgian and demonstrates his/her ideology, originate from the word "mother". Such words are: "Dedaena" (Native Language), "Dedabodzi" (the main supporting pole of the house roof), "Dedamitsa" (Earth), "Dedakatsi" (the composit of the words "man" and "mother"), "Adgilis Deda" (mother of place - in the Georgian mythology, it is name of a woman guardian idol), "Gutnis Deda" (plow mother - this term also is the composition of the Georgian name of a working instrument and the word "mother" and was used to indicate a man tilling the soil).

The most important features of Georgians identity, and among them - religion, is associated with the women characters. According to the historical traditions, the convertor of Georgia to Christianity was St. Nino and according to the ecclesiastical history, Georgia is also considered as the country protected by the Virgin Mary.

In important political and cultural processes women participate at all levels of the history of Georgia. One of the earliest Georgian hagiographical manuscripts "Martyrdom of Shushanik" (V c.) is included in the school program, where the main character is a woman, who had rebelled against her son and her husband. The character of the woman - the queen Tamar (1160-1213) is shown in an interesting way in the Georgian historical writing [1].

The Georgian historical masterpiece "The Knight in the Panther's Skin" is devoted exactly to the queen Tamar. The oral retellings about women warriors (i.e. Tamar Vashlovneli, Maia Tskneteli, whose adventures were depicted in folk retellings, cinema and theater, a feature-length film "Maia Tskneteli" was made as well) or about the nurses of the heroes (Mother of Nine Kherkheulidze Brothers) are also interesting, which passed from generation to generation through the centuries as the examples of right lifestyle.

The theme of femininity has been still important in the following periods. In 1958, on the 1500 anniversary of Tbilisi, the monument of "Kartlis Deda", was put up. A wooden 20 meters high monument was covered with aluminum and became one of the most outstanding symbols of the capital of 
Georgia (in Georgian, the capital is composed from the words "mother" and "city"). The twentieth century sculptor revived the image of a woman that had developed through the ages and had been inculcated in the imagination of the Georgians. The woman, dressed in Georgian national clothes, holds a sward in one hand as the symbol of power and a bowl in another - as the symbol of Georgian hosting traditions.

As we can see, the cult of a woman that had been developed in the Georgian consciousness even in the ancient past, is associated with the most important historical processes. But the stereotype of a woman created in the consciousness of the Georgian society is associated with the acknowledgement of motherhood, in particular, fulfillment of publicly sacred duties by mothers-to-be or already become mothers. Accordingly, studying the historical and cultural meanings of a woman/a mother is important both for the development of civic self-consciousness and understanding the essence of its features.

\section{SELECTED SOURRCES AND THEIR RELEVANCE}

The Georgian hagiographic literature and their characters provide us with important information about the social status of a woman. In the given article, we shall review only a few of them in this literary genre. There are: "Conversion of Kartli" which is considered as one of the earliest written source (IV c.) of the Georgian history [2]. The two compositions are included in "Conversion of Kartli" (Kartli is a historical and ethnographical region of Georgia), one of which is the so-called "chronicles" about the $4^{\text {th }}-9^{\text {th }}$ centuries and the second one is "Life of St. Nino". The following composition is "Martyrdom of Shushanik", which belongs to the $5^{\text {th }}$ century and "The Vita of Grigol Khandzteli" that is the most important hagiographic composiion of the $10^{\text {th }}$ century.

Important sources about the social status of a woman are also given in the secular manuscripts, such as "Kartlis Tskhovreba" (a different edition of St. Nino's life is also given in this collection), which is the most important collection of Georgian historical writings (XI c.) and provides us with significant information about the social and political activities of women in various ages. The characters of the $12^{\text {th }}$ century Georgian poem "The Knight in the Panther's Skin" are women as well. There are other Georgian secular literary compositions about the social and legal statuses of women, but now, it is impossible to review each of them.

The $18^{\text {th }}$ century was defined as the upper level of chronology. First of all, we were interested in this period, because the named age coincides with the chronological framework of our doctoral study. Besides, we were interested if the economic and legal activities of women, depicted in the court ruling, were accidential or the results of an important social transformation.

A law, like other examples of human activity, depicts the values and ideological attitudes of any group. So, it is an important source for analising various complex and interesting issues and among them for studying women history as well.

The scientific study of the Georgian law has a quite old tradition [3]. But it should be mentioned, that the earlier researches, which we know and take into consideration, were carried out on the issues of legal status of women, by studying historical development of the Georgian legislation, not the femininity aspects. It is natural because most of the authors, considered by us, are the researchers of the period when studies on women and gender were not so actual.

As it is known, the formation of the Georgian law has quite long historical period and it was closely related to both the Eastern and the Western experiences [4]. It is evident from the historical sources that since the medieval Georgia, a woman had an active role in the heritage law. The existence of the dowry Institution since the ninth century is very important for determining the legal status of women. It is evident that a woman is not a thing any more, but she is a person [5].

This time, we have selected a legal document of the local Georgian ecclesiastical meeting "Regulations of the Ruis-Urbnisi Meeting”, which dates by 1103-1104 and is related to the name of the King of Georgia - David IV the Builder (1089-1125). The second is the "Writing the Manuscript by the King of Kings George" by George V the Brilliant (1286-1346). This legal collection known as "Dzeglisdeba" was created especially for the highlands of the Eastern Georgia, where together with the administrative issues was made an attempt to define the social and legal statuses of women. The following source is "The Law of Vakhtang VI" created in the beginning of the $18^{\text {th }}$ century by Vakhtang VI (1675-1737). Actually this manuscript represents former legislative life of Georgia [6]. Highly interesting is the legal acts and regulations issued by the King of Erekle II (1720-1798).

An invaluable source is the legislative project, created by David Bagrationi (b.1767-d.1819), known by "The Law of David Batonishvili" (1800). It should be said that the legal activity by David depicts general principles of ideology of the Georgian cultural elite in the eihteenth century and their affinity with the enlightened ideas [7]

We think that as the selected sources represent different sides of history of the Georgian unity they are relevant for our research.

\section{Legal Status of WOMEN IN THE MiddLE AgES ACCORDING TO THE GEORGIAN LEGAL DOCUMENTS}

The first document, we want to discuss, is the "Regulations of the Ruis-Urbnisi Meeting" (1103-1104). Despite that the "Dzeglistsera" (regulation) is an ecclesiastical legislative document and as the Georgian academician - Ivane Javakhishvili rightly says, the Meeting, by its character, should be a special congress in total [8]. As it is evident from the content of the document, the goal of this Meeting was not only solving the ecclesiastic dogmatic problems, but arranging the practical and organizational issues and regulating the relationships between the ecclesiastical and secular spheres.

In this document, we find some important parts. The law 7 prohibits marriage of infants before their full age and the lowest limit was 12 years for girls. As it is evident from other laws, in particular, the regulations of the laws 13 and 14 were mostly related to the representatives of high social stratum [9]. 
But in the paragraph 7 , the represented prohibition is interesting from the point of genderization of age, as the professor Mariam Chkhartishvili points out, by studying the hagiographic work of "Martyrdom of Shushanik" (V c.) underage was not genderaized [10], but in "the Regulations of Coronation" of the manuscript, written after the Meeting underages is genderized. In particular, members of the meeting differenciate men and women among the underagers. The age limit of marriage is also interesting that is established in the document. It is evident that 12 years old child did not belong to the category of an infant or an underaged, but, according to the context of the document, we should think that such a regulation was in concern to the political marriages, where there was no real marital relationship. Thus, admition of 12 years as the high level of nonage would be incorrect and we should assume that, its level was in fact higher.

The goal of compiling the legislative collection of laws "Dzeglisdeba" by George V, the Brilliant (XIV C.) was to improve the destroyed legislative relationships after the supremacy of Mongols in the highlands of Eastern Georgia [11]. This document is interesting in many respects and especially for the history of Georgia.

The first chapter, where a source of the legislative status of women is discussed, is about the issues of death of "mothers, fathers and brothers". It is evident from the article 18 that, if a woman did not get married again after the death of her spouse, the family of a dead man should run the share in the property with the widow so as the spouse had appertained.

A separate chapter is devoted to the issues of abandoning or taking a wife away. It is evident from the article 21 that if a man unreasonably left/divorced with his wife, he would be obliged to pay compensation to her family. In the article is 22, the issue of a man taking smb's wife away is discussed and as it is evident from the document of "Dzeglisdeba", that the victim was not fined if he did not commit any crime against the abductor, and among them, did not raid or destroy his property during one year for kidnapping his wife. The article 23 is also about the kidnapping of the wife. This case is differ in that the article deals with taking the married wife away. Here as well, as in the previous article, in the case of taking smb's wife away, the family of the violator was charged with the fine equal to half of their property (together with the legal punishment, the fine was paid to the victim according to the social status of the family [12]). According to the article 24, when taking fiancée away, the fine was one sixth of the property. It is evident from the content of the above-given examples that those legal articles of the document "Dzeglisdeba" about women, are mostly developed according to the traditions and customs specific to the mountainous regions. The content of a legal document ("DzeglisDeba") reveals that a woman is the subject of the law, her judging still was according to traditions [13].

If the previous articles were about women, their main goal was to solve the legal controversy between men. In the same chapter of the legal document ("DzeglisDeba"), there are regulations in the article 25 that are only about women. One of such a regulation is about women warriors. In all probability, nobody would be fined in case of death of a woman warrior. It is also specially identified that if a woman was innocent or unguilty, in case of her killing, the murderer would be twice punished with blood feud. If a woman was a worshiper, then the blood feud would be equal to those of nuns and priests. We also find such an example, when a woman is the victim of a reckless homicide and in such case, the blood feud should be carried out according to the customs of her family.

The content of the article 25 deals with that a woman becomes the reason of her outcaseting for breaching the tradition of femininity in the socium when she fights as a warrior, despite it is not legally punished. In the following line, the discussions about the cost of a law-abiding woman is also reinforced by the terms "innocent" or "unguilty". In the last parahgraph of the same article, killing of a woman without an armour, whose mediator would be a nun or a priest especially emphasized. Of course, it implicates such a category of warrior women, who repent their "offence" and change their lifestyle, are twice punished with blood feud. In parallel to the legal responsibility, the goal of such a formulation of the law is to enforce a particular social discourse.

The following document, which we want to discuss is "The Book of Law" [14] by Vakhtang VI. Despite its informational and historical value, it suits the context of important historical and cultural transformations of the $18^{\text {th }}$ century.

Those articles of the law of Vakhtang VI, which are about the issues of women's rights, are closely related to the earlier Georgian legal documents, among them to the above-mentioned document "Dzeglisdeba" by George the Brilliant. For example, the article 62 is about killing an innocent wife by her husband and one part of the punishment is the compensation of material damage and the second one is the legal punishment. In the same article, in case of a suspicion against the son-in-law, the family members of the murdered may appeal to a court. In the following article 63, the case is about wounding or hurting wife by a man. In such case, the woman could appeal to a court and demand calling him to account. In the same article, it is underlined that in case of domestic controversy, such as the marital treason, it is not allowed to divorce the couple married in church. The article 64 deals with family violence. The action, when a husband tortures his wife, is severely punished. But as it is evident from the same article, other cases of controversy between the same couple would be decided either individually or by the Catholicos.

The following articles are about the crimes committed by a woman. The article 65 defines such a case, when a woman kills her husband. Thus, we have not discussed the particular legal rule how to decide such a controversy and it is totally dependant on the court decision, the case, that it was necessary to establish the truth and conducting investigation, and which could be closed by her discharge, indicates to her relatively improved legal status. Such action, as beating a husband or physical offence was punished. As we can see, the issues of legal responsibilities of a man and a woman in above given articles are equal.

In the article 66, it is defined that the devorce of the spouses was not advisable, when they hated each other and the Cahtolicos should attampted to reconcile the spouses. The article 67 is about the case of the treason against the husband. It is evident from this article that if husband condoned his wife, then nobody else could bring her to account. As it is evident from the legal regulation, this article is also interesting in that 
the law also included recklessness of the woman's society (It is different from the document of "Dzeglisedeba", where the opinion of the society was decisive).

In the same article, there is also given an example, when the treason against the husband is finished by a divorce. In such case, if a wife had a child, which was not the common one with the legal spouse, then the husband was obliged to give back all the dowry of his wife together with their child. But if the woman had a child from this legal marriage, then she should leave the child and part of her dowry, as the inheritance of her child, in the family of her ex-husband. The husband and the child did not have the legal right to demand part of the dowry, which would be spent by the woman during her marriage.

The following article 68 is about the relationship between the "betrayer" woman and her partner. If a man legally married a woman, having the common child, then he would not fined by her family and would only carry out blood feud against the ex-husband. If the new partner of a woman rejected to marry her, then he would have to carry out blood feud against the ex-husband. The woman would still keep her dowry if her partner did not marry her after the betrayal and they did not have a common child.

The article 69 is about "match-making". It is evident from the law, that such an act was punishable and together with the physical punishment it also considered fine. The content of the article 69 and its iclusion in this part of the law makes us to think that it is only about the match-making in the legal families. It is proved by the article 70 with the case, when a man carries on a flirt with a married woman. This article is interesting because if a woman neglected flirtation despite the sympathies towards the man and it was known to the family of a woman, she would not be punished.

The article 71 is about the flirt by a man towards the wife of another man. In any case, had he or not sexual relationship with this woman, he would be fined by her husband. If it is proved that he only flirted and nothing more, then he would have to pay half of the fine. Despite that the articles 67-71 are include the restrictive norms in the private life of the spouses, the fact that abandonment of the wife so as of the husband became the cause for the property controversy, indicates to the development of the natural law.

As it is evident, in special cases, the law does not define particular punishment and admits the possibility for the judge to pass individual judgment. It is about the committed crimes such as domestic violence. In the article 82 , exactly such an example is discussed and it is about killing a brother by a sister or vise versa.

The article 86 is about such a case, when a man has the relationships with other man's wife. The law by Vakhtang differentiates two types of fine: if a husband decides to keep the marital relationships with his wife, the guilty is obliged to pay half of the fine, whereas if the husband abandons his wife, then the guilty is obliged to pay the full sum of the fine. The article 87 is about the contrary case, when a wife catches her husband with another woman. In this case, it is interesting that if the woman informed the husband about his wife's betrayal and if the husband turned her out of the house, in this case the husband was obliged to pay fine. But if the husband condones his wife and preserves her as well, then the controversy, arisen due to reminding the betrayal, would be solved in her favor.

The following chapter 131 is about giving back the loan, where a woman is a successor of her husband. In the chapters 145 and 146, a woman is successor of a man as well. The chapter 145 is about the case, when the successor of a dead man is a woman. The woman passes on father's property and the loans of a husband to herself. Especially is defined the case, when a woman gets married before the death of her father and in this case, the plaintiff could not make the dowry the subject of property or loan controversy. It is also interesting, that the article 146 defines that the loan of a dead man would not be paid by the property of a mother or a sister.

Despite that the law by Vakhtang differs from other earlier documents and a woman is a person of law, the influence of customs law is not still overcome. The situation improves in the governance period of Erekle II (1720-1798).

In the second half of eighteenth century the worsening of the influence of Iran and Turkey in the Georgian kingdoms and principalities was suitable for the economic and political stabilization [15].

Erekle II, during his kingship supported to the cultural movement initiated by Vakhtang VI. Formation of educational system and supporting the accessibility of education was the most important prerequisite for developing the complex system of the Georgian consciousness and values. It turned out from various historical sources that king Erekle also worked on the reform of the Georgian law. It is evident from issued decrees by king Erekle that he relied on various legal and among them on non-Georgian experience in his law-making activity [16].

Those facts also prove the progress of law-making activity, which aimed reinforcement of not only the central government, but also the civic life, legal and economic status of the representatives of low social strata [17]. It should be pointed out that the municipal rule of property established by the king Erekle, according to which the property of a dead person was issued not as the land owned by a feudal lord, but was distributed among his relatives [18]. The legal activity of king Erekle about issuing the legal acts and decrees will be discussed in the following part of the article.

As for the above-mentioned last legislative collection "Law of David Batonishvili" by David Bagrationi, it should be said his law is more a natural than customary law. It was created according to the ideas of educational philosophy and the theory and practice of enlightened absolutism [19].

It should also be mentioned that the law of David, like the rule-making activity by king Erekle, is differentiated from the Georgian law according to various features. Despite that they did not share the legal traditions established in the Georgian law, orientation on the low social strata made their rule-making activity a part of public and educational movement.

For example, if the property rights of a woman were also granted in earlier Georgian legal documents, then the detailed description of this part of the law of David make the law more powerful. About the dowry of a woman, David says that a husband has no right on it, except the case, when the wife herself allows him to dispose the dowry. As we shall see in the following part, in the property controversy existed between the spouses, in reality, women used to claim the rights. It is 
evident from this chapter that a husband was obliged to give back all the chattels real and chattels personal, but also the part of the property that was acquired by using dowry of a woman. Such a case is also discussed when a woman intestates her property to her husband. If earlier, the reason of divorce was considered betrayal and it was necessary to bring the couple to an agreement without their divorce, in the document by David, about the definition of the reason of divorce, it is said: "for leaving free and by the reasons of others" [20].

As we see in the eighteenth century the dowry for a woman was not only the ancestral estate, but also guarantee for her economic independence, so that she could carry on economically and interesting profitable business by her own will.

\section{V.SOCIAL STATUS OF WOMEN}

While discussing the past of the social and economic statuses of women, it is necessary to consider various historical sources. Despite the official documents, an important information is kept in the secular and ecclesiastic literary documents.

The first written source, which we shall discuss, is the "Life of St. Nino" from "Conversion of Kartli". This composition is interesting because it describes the process of implementation of Christianity in Kartli as an official ideology, "when the new ideology of Jerusalem developed as the sacral center of the Christian universe" [21]. In this process the most important character was St. Nino. The saint is represented as a man of principle, who rejects the proposed economic privileges for defending her own opinions [22]. She rejects the plan of ideological and religious transformation proposed by the king Mirian, according to which Nino should extend the local religious tradition. It is mentioned in a specific literature that "the missionary woman took place of a pagan or an idol of the nursing mother. To include the information about the protector mother, the "file" named "Nino" (or Mother) had already existed in the historical memory of the Georgian unity" [23].

One of the Authors of "Kartlis Tskhovreba" (Life of Kartli) Leonti Mroveli describes the character of St. Nino as it follows: "I see your power, as the power of a lioness, who calls for all quadruped, as the female eagle, who reaches more height than the male eagle" [24].

It is natural that we do not exaggerate the attitude towards the woman who converted Kartli to Christianity. The status of holiness does not make her subject of general discussions. But in our opinion, that the heroes of the historical and hagiographic compositions, which had the customers not only in higher social society, become rebels or reformatory women and their histories point to a certain trend.

It is obvious from the literature of this period that the social activity of a woman was closely related to her religious activity. If they seemed to be limited in other spheres of the public life, then they had an important position in religious aspects, except the hierarchical. It should be said that the image of a religious woman in the Georgian consciousness was implemented by strengthening St. Nino's life and improving the religious tradition in Georgia of the mother protector.

The Christian model of the hierarchical order between a woman and a man did not change the order of the patriarchal society. The image of a religious woman became a clue for an active woman to realize her goals so that she did not entirely destroy the relationships.

One of the earliest Georgian hagiographic compositions, which provides us with interesting sources about the gender issues, is "Martyrdom of Shushanik". This document as well as the "Life of St. Nino" has already become the object of observation, thus, to generate the women issues, it is appropriate to bind certain ties between them.

The stories described in the "Martyrdom of Shushanik" take place about 120-130 years later than St. Nino's life. As we have mentioned above, after St. Nino's activity, the image of an active woman included the religious and ecclesiastical works. So, it should not be casual that the author names the rejection of Christianity as the main reason of conflict between the Shushanik and her husband. He underlines the fact that Shushanik was the protector and faithful of the Christianity from her childhood [25].

The position of a religion protector makes Shushanik not only the character of a religious story, but as a participant of the particular political process like St. Nino. When Varsken changed his faith by his own will, he made a political choice in the favor of the King of Iran. Varsken had claims towards Shushanik not only about the religious incompatibility, but because his wife did not share his political opinions as well. It is proved by the fact that Varsken is not a fighter against the Christianity. One of the reasons of pointing out the multiplicity of Shushanik's fandoms by the author was that the religious and political views had more supporters than her husband [26]. We guess from the text that Varsken also felt it and was afraid her wife not to get married to any nobleman that could aggravate his status [27]. It should be said that the character of Shushanik has improved the image of a religious and an active woman.

As we have mentioned above, the religious role turned out to be suitable for women, where "women and men are not discriminated" [28]. Thus, the religious tradition did not mean the equity of men and women in the life of the world, but such an extension of the religious tradition in the Christian culture had an impact on formation of secular opinion.

In pre-Christian era, the narrative developed in the following period in Georgia, continues to exist. But it is processed by the religious and gender views. From this point, the story of Zeno and her sister given in the text of "The Vita of Grigol Khandzteli" (X c.) is also interesting. Zeno had become a nun after the death of her parents and by her own will had got married to an un-known man that prevented from becoming her a nun [29]. As we see, we have the image of a secular woman in the Georgian narrative of the medieval century together with the religious one. Zeno's sister, differ of the above-mentioned characters, was motivated not by caring about public interests but by her personal will.

In the later texts of the "Kartlis Tskhovreba" (Life of Kartli), we find the religious women characters as well as women as the participants of the political life, whose motivation is not the protection of a religion but maintaining 
the political power and development.

The twelfth century is on of the most important periods in the history of Georgia. The political union of the country, military and economic success made the conditions suitable for the development of the public life. In our opinion, the image of a secular woman together with the image of a religious one, in the narrative of this period, was improved and legitimated. If the behavior of Zeno's sister by her own will is considered as unacceptable for the society, then in the case of the Queen Tamar, resistance to the public opinion, and among them, to selecting a husband, is the result of the author's prudence and wisdom [30].

Tamar was the first woman Queen in the history of Georgia, who came to the throne. It had been preceded by an important controversy in the royal family, that finished by death of the king David V (1155-1156) in an obscure situation after his six months reigning period. Later, his son Demna (Demetre), by the support of one part of the nobles, tried to restore his legal rights by the revolt. After his prisoning, blinding and castration, he died in 1178 and only after that, in 1179, George announced Tamar as his co-regent.

The time, when George III, Tamar's father became the king (in 1156) and especially the reign of Tamar needed faith and acknowledgement by those Georgian secular rulers, who had questions about the legitimation of the royal power after the controversy in the royal family. In the texts of "Kartlis Tskhovreba" (Life of Kartli), according to the historical data about Tamar and her reigning period, the king Tamar is presented not as a religious woman or mother, but as an independent, wise judge and a strong ruler, when Georgia achieved an unseen success [31].

So, the strengthening of the public and political role of a woman in the document of "Kartlis Tskhovreba" was related to important political processes and it is not an exaggerated if we say that finally, the authors, despite their initial goals supported to the change of traditional opinion about the social role of a woman. There are not so many oral stories about any king of Georgia, as the number of the stories about Tamar. The multiplicity and complexity of these stories makes an impression of a well-organized campaign. As it is obvious, it was necessary to create loyal attitudes of the low social strata in the ruling society towards the new cultural postulates improved as a result of current intellectual transformation.

The concept of gender mentioned in his poem "The Knight in the Panther's Skin" by Shota Rustaveli - "cub of the lion is equal, let it be male or a female" [32], despite that he meant the representatives of high social strata, and in particular, the members of the royal family, anyway, it is the reformatory alternative of the existing traditional attitudes. He also, like the texts of "Kartlis Tskhovreba" (Life of Kartli), improved the plot by presenting a woman in a different role. The Georgian literature is aware of many such compositions which are devoted to the character of the king Tamar. Despite the difference in literary and artistic values, it should be said that main theme for each of them was a strong woman. Despite this, the providential attribution towards femininity is still an insuperable problem.

The situation changes in the eighteenth century: as we have mentioned above, the important information about the social and economic status of women also is included in the documents of economic content and the court judgment. The study of these resources is also interesting in order to check legislative regulation, how they worked in real life.

Dowry was established in the early period as a form of a contract between the spouses and it was included in the inheritance received from mother. As the academician I. Javakhishvili says, it was of two types and consisted of real estate together with the chattel personal [33]. It is evident from the books of dowry of various people dated by 1787 (\#163), the late $18^{\text {th }}$ century (\#232), 1807 (\#275), 1808 (\#279), 1813 (\#286), 1815 (\#295) and 1822 (\#311) that a woman was given dowry with both jewelry and domestic utensils (the last three documents are drafted in favor of the commons). It is obvious from the document released by Leon Batonishvili, that there was a tradition of a wedding gift as well [34].

The economic controversy by women reveals that, in the eighteenth century, they had not only private property, but could have independent court controversy and economically profitable operations in order to defend their property and financial interests.

The judgment issued on March 27, 1771 (\#16) makes it obvious that Natela, the daughter of any Osepa complaints against her own brother. Because of the financial problems, Natela had alienated the store, which was her dowry. As we learn from the document, her brother bought out the store and after death of their father, Natela claimed the property. Despite the evidences given by the witnesses, the court appertained part of the property as the dowry of the claimant. In the following controversy $(1779, \# 52)$, a widow of any Shakrua claims that her neighbor began to appropriate her property. It also turns out from the judgment, that Erekle II solved the controversy in favor of the widow. We also learn from the judgment of 28 February, 1781 (\#83) that was about the issue of Iesant Stephane's widow garden that any Galua had sold part of his land to stephane and the same Galua had alienated the other part of the land. Thus, because of indicating incorrect sizes of the lands, the land of Stephane's widow became controversial. After the questioning the witness, the court solved the controversy in favor of the widow. In 1782 (\#106), the property controversy of widow Okromchedlishvili was also solved in favor of the widow. It should be pointed out that the case was processed by the Queen Darejan. The following document (1785,\#183) is also about the property controversy arisen among women. The most important is that both of them were married, but the wives act as defendants at the court. We also learn from the judgment of 28 February, 1788 (\#237) that a widow of Terosepha also claims against her brother-in-law about the house. It becomes obvious that the brother-in-law had denied the property in favor of the sister-in-law [35]. Both parties are not the members of the governing society. They belong to the society of handicraftsmen and the low hierarchy of the priesthood.

It is obvious from the judgment of 28 February, 1802 (\#264) that the Abashidze's widow tries to solve the financial controversy by the court. We learn from the judgment of June 1, 1807 (\#274) that the widow of Avetika has the controversy with Avetika's child about the property. This judgment is interesting by that the right to property is determined there. It 
becomes obvious that the controversial property is the stepmother's dowry, the inheritance of her first husband and the inheritance of Osepha's parents [36]. The judgment of 22 June, 1794 (\#168) deals with the property controvercy between the spouses. It turned out that the husband had to compensate the sum spent from his wife's dowry [37].

Despite those cases, when a woman defends her rights on property through the court, we also meet such cases, when the women of the royal family are the initiators of the controversy and represent the judges of the plaintiff as well. For example, in the document dated by February 26, 1799 (\#196) it turns out that the queen charges the public officer to describe the dwelling of the servants. In the document dated by March 14, 1790 (\#65) it turns out that the queen is asked to solve the controversy among the claimant and the princes. In the follow-up letter, dated by march 14, 1790 (\#65) informs the claimant about the judgment of the tax controversy [38].

We learn from the document, dated by 1740 (\#87), that the queen Tamar gives the guarantee of immunity to the feudal Kaikhosro Tsereteli [39]. The document demonstrates the division of the government. The fact, when a woman, even a queen, has the right to give anybody the guarantee, or release a decree in the reigning period of the king points to a certain tendency. The chronological issue of the documents also indicates that the cases were individual and it was an ordinary practice in the eighteent century.

The medieval Georgian law regulated the rule established in advance about disposition of the inheritance property. It turns out from the testament, dated by February 4, 1799 (\#194), that a woman by her own will leaves her inheritance to the heiress of low and high social strata [40], and it can be understood as an act of gender solidarity, especially because she had heirs as well.

The activities of women are demonstrated in the documents of bills and the deeds of sale and purchase as well. The deed of purchase, dated by August 25, 1736 (\#61) is about selling the land to Anuka Batonishvili by Levan Abashidze [41]. In the deed of purchase dated by July 1, 1731 (\#29) the lender of money is a woman, who got monthly profit in percentage. As we learn, the financial transactions did not finish without conflicts and both - the lender and the borrower had to defend their rights through the court. The judgment dated by June 7 , 1756 (\#60) describes exactly such a case. Daughter of Khorazm Batonishvili claims against Javakhishvili for breaking the promise within the financial agreement and it is evident that financial usury was a norm for the representatives of the high social stratum. The document dated by 1761 (\#67) deals with lending money with interest rates. In this case, the lender is the representative of the lower social class. The interest in usury acts is proved by other documents as well. In particular: 1782 (\#83); 1784 (\#93), and in the document dated in 1785 (\#104) the money lender is a wife of a gardener. In the document of 1794 (\#164), there were cases of mortgaging jewelry [42].

The represented documents are only the part of those official documents issued in the eighteenth century, which describe the activity of women. It is a fact that women more participated in various activities than it was in the earlier periods. One fact also should be considered, particularly that the activities carried out by women were common for men. It is obvious from the Document of "Dzeglisdeba" that usury was considered as an unacceptable and evil act [43]. The participation of a woman in secular activity was related to its stigmatization and implementing the stereotype of a woman as an imperfect and morally unsustainable creature.

Thus, the eighteenth century, with its content about the gender relationships, was a progressive one and it should be said that it suited the general context of the development of society.

\section{CONCLUSION}

There are many interesting facts in the Georgian historical resources about the discussions on the social and legal status of women. Since the fourth century, after the official declaration of Christianity as the state religion, the concept of a religious woman and mother has developed in the local narrative. The attribution of the faith of a woman and motherhood was necessary prerequisite for participation in secular life. In the following texts of "the Vita of Grigol Khandzteli", the plot of Zeno's sister demonstrates the image of a woman rebelled against the society rules and the family.

The attribution of religious woman and mother ensues from the early Christian era to the late periods. Despite that, since the reigning period of Tamar, when a woman participates in public life, the ecclesiastic version of the equity between a man and a woman, by presenting the image of an independent and a strong woman, was not totally overcome [44]. It is proved by the document of "Dzeglisdeba" belonging to the fourthneeth century. Despite the fact that a woman is a person of law, anyway she is judged according to the local traditions. The document of "Dzeglisdeba" is familiar with the personality of a woman, both of a mother, a married woman or a widow. As for comprehension of a warrior woman, it is obvious that a woman, by such a manoeuvre, lost her social and legal statuses.

The eighteenth century represents the intellectual transformation of the Georgian unity. Anyway, the resources of this period demonstrate that the cultural elite perceives the image of a woman as an independent and legally, economically or politically active person. Thus, it is still impossible to differentiate the meaning femininity from the secular and social meaning of motherhood and faith. The fact is that, the ecclesiastical tradition transformed into the customary imaginations of the Georgians and still, a woman is represented as an obedient with high spirit and a private individual having priority duty of motherhood. The negative attitude towards the usurious capitalism in the Georgian community imaginations influenced on the genderization of social and financial relationships in the eighteent century. As we have seen, absolute majority of the money lenders were women.

The success of women in the activities, that were humiliating and unacceptable for men, supported to development of the hierarchical relationships among man and women. Finally, we can say that the intellectual transformation, that took place in the eighteenth century, had a significant influence on the gender attitudes, thus, it supported to the implementation of certain stereotypes. 
Finally we should note that it is impossible to discuss the issue entirely. We will consider our goal as achieved, in the case the given article will be like as a guidebook for interested persons.

\section{REFERENCES}

[1] "Life of king tamar the Great," Kartlis Tskhovreba, The text established according to all main manuscripts by S. kaukhchishvili, Tbilisi, Sabchota Sakartvelo,1955, vol. I. pp. 368-369.

[2] M. Chkhartishvili, "The image of mother - Nino - in historical memory of Georgian and king Mirian's religious reforms,"Amirani, 2008, \#19-20, pp.54-73.

[3] V. Metreveli. History of the State of Georgia and the Law. [Online]. Available: https://www.scribd.com/doc/242331129/

[4] I. Dolidze, Consuetudinary Law of Georgia, Georgian National Academy of Sciences, 1960, p. 124.

[5] G. Nadareishvili, Old Georgia Family Law, Metsniereba, 1996, p, 35.

[6] I. Dolidze, Activities carried out in the field of law by Vakhtang VI, Laws of Vakhtang VI, the text has been ascertained, research and glossary attached by Isidore Dolidze, Sabchota Sakartvelo, 1981, pp. 6-11.

[7] A. P. Rogava, "The comparison of reviews with the law projects," Reviews of Law and Jurisprudence of Georgia, Georgian National Academy of Sciences, 1959, p. 166.

[8] I. Javakhishvili, "History of Georgian law," book 1, part 1, works in 12 volumes, volume VI, 1982, pp. 53-54.

[9] I. Dolidze, "Law of the Assembly of Ruis-Urbnisi", Georgian Law Manuscripts, vol. 3, 1970, pp. 117-118.

[10] M. Chkartishvili, "Categorical perception of gender in the georgian society of the fifth century according to the "Martyrdom of Shushanik," Introduction to the Historical Sciences, Universali, 2009, pp.125-126.

[11] I. Dolidze, Law of George The Brilliant, of Georgia, Tbilisi State University, 1957, pp. 15-16.

[12] I. Dolidze, Old Georgian Law, Tbilisi State University, 1953, p. 190.

[13] G. Sharashidze, Introduction to Research of the Georgian Feudalism, (Writing of the Manuscript by George V). Ilia State University, 2011, vol. 2, pp. 97-98.

[14] I. Dolidze, Law of Vakhtang VI, the text has been ascertained, research and glossary attached by Isidore Dolidze, Sabchota Sakartvelo, 1981, pp.169-266.

[15] O. Gigineishvili, "Foreign policy of Turkey towards Georgia in the last quarter of the $18^{\text {th }}$ century," Iran in the Second Half of the $18^{\text {th }}$ Century, Metsniereba, 1970, p. 3.

[16] A. Rogava, Review of the Georgian Law and Jurisprudence (research paper), with the edition and studies by Apolon Rogava, Georgian National Academy of Sciences, 1959, pp. 37-40.

[17] G. Akofashvili, "Nobility and the Kingdom Authority in Eastern Georgia of $17^{\text {th }}$ and $18^{\text {th }}$ Centuries,"Materials for the History of Georgia and the Caucasus, 1963, part 35, pp. 115-139.

[18] M. Dumbadze, "Protection of the serfdom order, Fight for the increase of the income of the Kingdom and the industrial development of the country", Essey on history of Georgian, Sabchota Sakartvelo, vol. IV, p. 527.

[19] D. Purtseladze, Law Book of David Batonishvili. Text published and study attached by D. Purtseladze, Metsniereba. 1964, p.7.

[20] D. Bagrationi, Law Book of David Batonishvili. Text published and study attached by D. Purtseladze, Metsniereba. 1964, p. 41-42.

[21] M. Chkhartishvili, "Life of staint nino" and the contemporary problems in the science of history: Ethnicity, hierotopy and gender,'St. Nino, N1, Artanuji, 2008, pp. 423-453.

[22] I. Abuladze, Old Georgian Hagiographic Literature, Georgian National Academy of Sciences, 1963, part 1, pp. 131-132.

[23] M. Chkhartishvili, "The image of mother - Nino in historical memory of Georgian and King mirian's religious reforms,"Amirani, 2008, \#19-20, pp.56.

[24] L. Mroveli, "Life of saint nino," Kartlis Tskhovreba, The text established according to all main manuscripts by S. kaukhchishvili, Tbilisi, Sabchota Sakartvelo, 1959, vol. II. p. 77.
[25] I. Khutsesi, "Martyrdom of shushanik," The Georgian Writing, Nakaduli, 1987, vol. I. pp. 224-225.

[26] "Martyrdom of shushanik," The Georgian Writing, Nakaduli, 1987, vol. I. pp. 233-234, 241.

[27] "Martyrdom of shushanik," The Georgian Writing, Nakaduli, 1987, vol. I. p. 237.

[28] "Martyrdom of shushanik," The Georgian Writing, Nakaduli, 1987, vol. I. p. 241.

[29] G. Merchule, "The vita of grigol khandzteli," The Georgian Writing, Nakaduli, 1987, vol. I. pp. 546-547.

[30] B. Ezosmodzgvari, "Life of the king of kings Tamar," Kartlis Tskhovreba, The text established according to all main manuscripts by S. kaukhchishvili, Tbilisi, Sabchota Sakartvelo, 1959, vol. II. p. 120.

[31] "Life of the king of kings Tamar," Kartlis Tskhovreba, The text established according to all main manuscripts by S. kaukhchishvili, Tbilisi, Sabchota Sakartvelo, 1955, vol. II. pp. 368-369.

[32] Shota Rustaveli, The Knight in the Panther's Skin, Metsniereba, 1988, p. 15.

[33] I. Javakhishvili, "History of the Georgian Law", book I, part 1, works in 12 volumes, 1982 , vol. 7, p. 35-36.

[34] Resources for the History of the Economics of Georgia (Building, State Economics, Property), Resources selected and prepared for publication by Niko Berdzenishvili, Stalin State University, 1955, vol 3.

[35] The Manuscripts of the Georgian Law, "The Court Rulings", The text published, introduction and glossary attached by Isidore Dolidze, Metsnereba, 1977, vol. 5.

[36] Resources for the History of the Economics of Georgia (Building, State Economics, Property), resources selected and prepared for publication by Niko Berdzenishvili, Stalin State University, 1955, vol. 3 .

[37] Resources for the History of the Economics of Georgia (Loan, Lease, Trade), resources selected and prepared for publication by Niko Berdzenishvili, Tbilisi State University, 1953, vol. 2.

[38] Resources for the History of the Economics of Georgia (Building, State Economics, Property), resources selected and prepared for publication by Niko Berdzenishvili, Stalin Tbilisi State University, 1955, vol. 3

[39] Historical Documents about the Kingdom of Imereti and the Principalitoes of Guria and Odishi (1466-1770), The text published, introduction and glossary attached by Shota Burjanadze, Georgian National Academy of Sciences, Institute of Manuscripts, 1959, vol. 1.

[40] Resources for the History of the Economics of Georgia (Building, State Economics, Property), resources selected and prepared for publication by Niko Berdzenishvili, Stalin Tbilisi State University, 1955, vol. 3 .

[41] Historical Documents about the Kingdom of Imereti and the Principalitoes of Guria and Odishi (1466-1770), The text published, instroduction and glossary attached by Shota Burjanadze, Georgian National Academy of Sciences, Institute of Manuscripts, 1959, vol. 1.

[42] Resources for the History of the Economics of Georgia (Loan, Lease Trade), Resources selected and prepared for publication by Niko Berdzenishvili, Tbilisi State University, 1953, vol. 2.

[43] [I. Dolidze, Law of George The Brilliant, Tbilisi State University Publishing House, 1957, p. 119.

[44] Basili Ezosmodzgvari, "Life of the King of Kings Tamar", Kartlis Tskhovreba, The text established according to all main manuscripts by S. kaukhchishvili, Tbilisi, Sabchota Sakartvelo, 1959, vol. II. p. 126, 136.

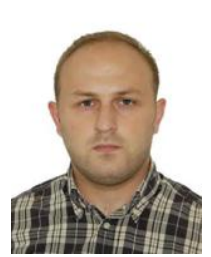

Zurab Targamadze is a $\mathrm{PhD}$ student at Ivane Javakhishvili Tbilisi State University. Sphere of his interest is studing Georgian ethnic and national identity in medieval and modern period. He also participated in various scientific projects and conferences which has been focused on other issues of Georgians history. He is member of editorial board of the scientific journal "Georgian Source-studies. 